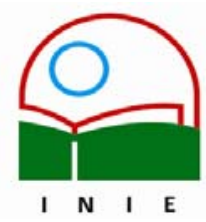

Universidad de Costa Rica

Facultad de Educación

Instituto de Investigación en Educación

ACTUALIDADES INVESTIGATIVAS EN EDUCACION

\title{
A SAMPLE LESSON PLAN FOR THE COURSE ENGLISH COMPOSITION II
}

\section{Patricia Córdoba Cubillo ${ }^{1}$}

\begin{abstract}
The goal of this article is to present a lesson plan and a series of sample tasks to help the instructors from the course English Composition II, at the School of Modern Languages from the University of Costa Rica, to guide students write an essay integrating the four skills: listening, speaking, reading, and writing. These activities will be a source of comprehensible input for the learners that will hopefully result in a good writing piece.
\end{abstract}

Key words: IMPORTANCE OF THE READING AND WRITING SKILLS/ LESSON PLANNING/ SUGGESTIONS FOR FURTHER RESEARCH IN THE FIELD OF WRITING IN EFL/

Resumen: El objetivo de este artículo es presentar un plan de lección y una serie de actividades que le ayudarán a los y las instructoras del curso Composición Inglesa II de la Escuela de Lenguas Modernas de la Universidad de Costa Rica a guiar a sus estudiantes a escribir un ensayo integrando las cuatro macro-destrezas, a saber comprensión auditiva, conversación, lectura y escritura. Mediante estas actividades se espera que los estudiantes elaboren un ensayo de calidad.

Palabras clave: IMPORTANCIA DE LAS DESTREZAS DE LECTURA Y ESCRITURA/ PLAN DE LECCIÓN/ SUGERENCIAS PARA INVESTIGACIONES FUTURAS EN EL CAMPO DE LA DESTREZA DE ESCRITURA EN $E F L /$

\section{Introduction}

This article will present a lesson plan and its corresponding tasks that pursue to help students from the course English Composition II write an essay. This is a second -year, second- semester course for the English and English teaching majors at the University of Costa Rica. It belongs to the second year, second semester of the major already mentioned. One of the purposes of these activities is to have a class in which all the four macro-skills: listening, speaking, reading, and writing will be integrated so that students can practice and reinforce those skills in their learning process. Another objective is to provide these learners with enough and comprehensible input that will help them produce an excellent- quality essay. Not only the activities chosen for this class, but also the topic to be developed

\footnotetext{
1 Magíster en la Enseñanza del Inglés como Lengua Extranjera; Licenciatura en Lingüística, Bachiller en Inglés, Profesora de Enseñanza Media en el ramo de Inglés, todos los títulos de la Universidad de Costa Rica. Profesora de la Escuela de Lenguas Modernas de la Universidad de Costa Rica. Tiene
}

Correo electrónico: pcordoba@racsa.co.cr

Artículo recibido: 27 de agosto, 2004

Aprobado: 28 de marzo, 2005 
throughout activities are intended to be useful and motivating for the students. Once this process is finished, the students will be ready to do their writing task, which in this specific case is a comparison/contrast essay.

This article also pretends to demonstrate that writing should not be presented as an isolated skill. On the contrary, if we, as instructors, want to obtain good results, it is necessary to start incorporating the other macro-skills in our classes. If we, as instructors, do this, the students will be eager and willing to take an active part in the learning process and become responsible of their own learning.

\subsection{Review of Literature}

Even though the main goal of the course English Composition II is not reading, reading becomes an important skill or tool to develop and practice in order for the students to have enough comprehensible input, that in the long run, will benefit them while writing. Thus as Nunan states when quoting Rivers and Tamperly (1978, p.187), reading serves many purposes. According to them, one of the reasons of reading is to obtain information for some purpose or because we are curious about some topic; another is to get instructions on how to perform some task. These are the purposes that apply to English Composition II since students are required to do some reading before they start their writing task.

Reading has sometimes been disregarded and not been given the importance it has in the learning of a language because it has been considered a passive skill. The reason for this is that there is only decoding of the written language by the reader. However, as Goodman (cited by Gollasch, 1975) states, reading is a receptive process; it is a psycholinguistic process in that it starts in the linguistic surface representation encoded by a writer and ends with meaning which the reader constructs. There is thus an essential interaction between language and thought in reading. The writer encodes thought as language and the reader decodes language to thought. As clearly seen, it is a two-way process.

The concept of ESL reading as a bottom-up model sees reading as an interactive process. Widdowson, as cited in Grabe et al (1996), claims that reading is considered as the process of combining textual information with the information a reader brings to a text. In this view, the reading process is not simply a matter of extracting information from the text. Rather, it is one in which the act of reading activates a range of knowledge in the reader's mind that he or she uses, and that, in turn, may be redefined and extended by the new 
information supplied by the text. Reading then is viewed as a kind of dialogue between the reader and the text. It can be said that reading is an interpretive process because of the interaction that occurs between the reader and the text. This interactive approach emphasizes that meaning is not present in a text waiting to be decoded. On the contrary, meaning is created through the interaction of text and reader.

In this point, it is important to refer to the concept of background knowledge or schema that facilitates text comprehension. When we read, we extract information according to the purpose of our reading, our interests, our needs, our motivation, our experiences, and others. We use our knowledge of the world and our previous experience -schemata- as readers to make sense of what we read. This background knowledge enables us to understand ideas, concepts, and points of view and to integrate them into our experience. While reading, we develop expectations based on this prior knowledge of texts and of the world to verify them [the expectations] on the basis of input from the text.

I believe that those projects in which students are required to write should focus mainly on reading, and when students write, they can make use of their knowledge of the world and of their experience as readers, and this is what I pretend do with the students taking the course English Composition II and expose them to a reading excerpt prior to their writing task.

It is important to point out that in most EFL classes, reading and writing activities or tasks are usually interdependent. Instructors frequently use writing to check reading comprehension, or they use reading to prepare students for the writing task. This is so because instructors often want to provide their students with comprehensible input or with models for their writing tasks.

Regarding this former aspect, Eisterhold et al (1990) mention that:

it is necessary to refer to the reading and writing abilities in the $\mathrm{L} 1$ and $\mathrm{L} 2$ of $E F L$ or ESL learners to determine the relationships across languages. They claim that literacy skills can transfer across languages, but that the pattern of this transfer is different for the two language groups. They found out that the reading ability transfers more easily from the L1 to the target language or L2 than does the writing ability, and that the relationship between reading and writing skills varies for the two language groups.

For these researchers, learners make use of two main sources to construct a second language system: knowledge of their first language (interlingual transfer) that is related to 
their literacy skills and knowledge of literacy practices, and input from literacy activities reading and writing (intralingual input). These two sources are used by L2 learners in acquiring second language literacy skills as happens with the LM-1245: English Composition II students.

According to Krashen (cited by Ferris, D. and John S. Hedgcock, 1998, p. 22), "students obtain more knowledge and learn more efficiently when abundant and meaningful input is provided to them.". This communicative instruction expands to the ESL composition setting, where many instructors believe that nearly any kind of reading is beneficial to apprentice writers. Thus, many ESL writing courses are based on the premise that "writing competence results somehow from exposure to reading, and that good readers make good writers" (Carson, 1993, p. 85).

Hughey et al. (1983) state that:

writing is an efficient tool that helps ESL reinforce other language skills. Reading, vocabulary, and grammar are skills used and present in the writing process. As ESL learners become actively engaged in the writing process, they read for additional information, and they may do this to find answers or clarify positions about different topics students. As they read, they become aware of different writing styles as well as new vocabulary words. The reading skills are also reinforced because learners read for a purpose -to gain information. As they do this, they interpret, select and reject information that may or may not be used in their writing task. Writing also helps students to reinforce vocabulary skills since they must search for the most suitable words required for their writing task. Grammar patterns are also enhanced by writing. When learners write, they have to make decisions on the most appropriate patterns, sentences, tenses, among other features, required for their writing.

Since writing represents a means to learn and reinforce skills, ESL students must know and realize that the ability to write is crucial in their process of language learning, and that they will be more effective writers once they comprehend that writing is a process, and as a process it has stages that can be identified and elements that can be learned. Thus, the instructor's role is to provide the learners with methods, materials, activities, and tasks necessary to understand those stages of the writing process and opportunities to engage actively in this process. 


\subsection{Methodology}

\subsubsection{Subjects}

The subjects of this study were students enrolled in the course LM-1245: English Composition II. They are majoring in English and English Teaching at the University of Costa Rica. The writing course belongs to the second year, second semester of their curriculum. Their ages range from 20 to 25 . Their level of language proficiency is high intermediate. The course meets once a week during three hours.

\subsubsection{Instruments}

Students were given two different charts to fill in (Pre-reading activity and Pre-writing activity), a reading piece (Appendix $A$ ), ten questions about the reading (Appendix $B$ ), a peer review checklist (Appendix $\mathrm{C}$ ).

\subsubsection{Procedures}

Students had to do the exercises and to perform the activities of the pre-reading, whilereading, post-reading, pre-writing, while-writing, and post-writing activities. Different grouping techniques such as individual work, pair work, group work, or whole group work were implemented to get the exercises or activities done.

\section{Lesson Plan}

The lesson plan was specifically designed for the course LM-1245: English Composition II. Since this course met weekly for three hours, the activities were planned to take approximately 9 hours, which were three different class periods.

\subsubsection{General Objective}

Students will get ready for writing a comparison/contrast essay by integrating the four macro-skills: reading, writing, listening and speaking.

\subsubsection{Specific Objectives}

1. To activate the students' background knowledge by reading an article and watching a video.

2. To discuss about negative and positive characteristics that fathers may present. 
3. To compare and contrast by writing an essay.

4. To exchange essays for peer correction.

5. To take into account the peers' corrections and comments when rewriting the draft.

\section{Pre-reading Activities}

\subsection{Video watching: Instructions for the students:}

1. You are going to watch a video segment called The Joys \& Risks of the "DaddyTrack." Pay careful attention to what is going on in it. This segment lasts approximately 4 minutes.

2. When the video finishes, write what you think the topic of the lesson is going to be about.

3. Once you have finished writing your guesses, turn around and discuss with your partner what each of you wrote. Decide on one topic. You have approximately 10 minutes to do this.

4. Then share the information with the rest of the students and pay attention to similarities and differences.

3.2 Being a father is a difficult task. There are positive and negative characteristics that may describe a father. In the table below, there are five characteristics already listed. Get in groups of four and discuss them with your classmates. Decide if these characteristics are positive or negative. Place a check mark $(\sqrt{ })$ next to the box in the table the group has agreed on. Think about the consequences, and decide whether they are good or bad. As a group, add at least three more characteristics you think are worth mentioning about being a father. Be ready to share your answers with the rest of the groups. You have 20 minutes to finish this task. 


\section{FATHERHOOD}

\begin{tabular}{|c|l|l|l|}
\hline Characteristics & Positive & Negative & Required \\
\hline Tolerance & & & \\
\hline Responsibility & & & \\
\hline Possessiveness & & & \\
\hline Strictness & & & \\
\hline Hard work & & & \\
\hline & & & \\
\hline
\end{tabular}

\section{While-reading Activities}

4.1 It is time to begin reading. You are going to read the text "The New Father" silently and individually. Pay attention to the vocabulary and the grammar structures used in this reading. Remember that the general topic of the lesson, Fatherhood, has already been discussed. You have approximately 15 minutes to read.

4.2 While you are reading, circle or underline all the words and phrases related to Fatherhood.

4.3 When you finish reading, make groups of four and review the words and phrases you circled or underlined in your reading and share your findings with your partners. 


\section{Post-reading Activities}

5.1 Once you finish sharing the vocabulary words and phrases, split up in pairs and do the following exercises based on the reading. Do not write anything. You have 15 minutes to discuss your answers orally.

1.What is one change about fatherhood mentioned in Paragraph 1?

2.What does the expression "be growing fat," paragraph 2, lines 1-2 mean?

3.What does them, paragraph 3 , line 7 refer to?

4. What is a similar word for infant in paragraph 3 ?

5.Why are quotation marks used in paragraph 4 ?

6 .What is the purpose of using but in paragraph 7 ?

7.What is the function of the hyphens (-- --) in paragraph 9, lines $14-16$ ?

8. What does it, paragraph 9 , line 13 , refer to?

9.What type of information does the word As in paragraph 10, line 7, introduce?

10. What is the main idea of the whole reading?

5.2 After your pair discussion, share your answers with the rest of the group.

\section{Pre-writing}

6.1 Your task is to fill in the following chart. You have to talk to three different classmates and write the information they will give you in the corresponding box. You have to ask them the following question: How have fathers' roles changed? 


\section{CHANGES ON FATHERS' ROLES}

\begin{tabular}{|l|l|l|}
\hline STUDENT'S NAME & OLDER FATHERS & YOUNGER FATHERS \\
\hline & & \\
\hline & & \\
\hline & & \\
\hline & & \\
& & \\
& & \\
\hline
\end{tabular}

6.2 Once you finish collecting the information, get in groups of four and discuss the facts gathered from your classmates. You have 15 minutes to do it.

\section{Writing}

7.1 Using the information gathered during the lesson, you are now ready to write and essay comparing and/or contrasting how fathers' roles have changed through time. In your essay, include some of the vocabulary that you learned from the reading as well as the appropriate comparison/contrast structures studied in class previously. Give your essay a suitable title.

\section{Post-writing}

8.1 When you finish your first draft, exchange it with a partner in order to do peer revision. Use the Peer Review Checklist provided. Remember it is important to do a thorough revision because the feedback you will get and receive is going to help you and your partner correct your essays and improve them. 


\section{Conclusion}

Writing is a difficult skill to teach if you do teach it in isolation. On the contrary, if in your planning for the writing class, you integrate the other skills that are part of the language process; you will discover that writing is an exciting skill to teach.

It is necessary to be aware of the importance reading has in the writing class. For the students, reading serves the following purposes:
a. activate schemata
b. relate prior knowledge to new one
c. recall and learn vocabulary
d. acquire review and grammar structures
e. be aware of different writing styles
f. keep motivated and interested
g. manipulate English.

For the teacher, reading provides opportunities to
a. develop warm-up activities in which students practice oral skills
b. give students exercises for reading comprehension
c. plan activities to provide students with pre-writing activities
d. create a motivating and relaxing atmosphere in which students feel relaxed when writing

\section{Suggestions for further research}

Mainly because the lesson plan and its activities presented in this article were designed for young Spanish-speaking learners of English a foreign language and for only one group of students taking the course LM-1245: English Composition II, it would be necessary to apply the same instruments to other students of LM-1245: English Composition II to find out if the activities prove to be as successful as they happened to be with this group of learners. Something interesting to do in other writing classes would be to have one experimental group and a control group and observe what happens to the group in which the reading skill is not integrated in the writing class. 
It may be important to do research in the writing class with different target groups, for example older adults, and observe what happens with their literacy skills. In this study, the role of errors in the writing class was not taken into account, but this could be an interesting area of study, mainly to find out if when reading is incorporated in the writing class, errors decrease, remain the same, or increase in the students' essays.

As can be seen, research in the classroom must be something continuous, and instructors must realize and be aware that research must be an important part of the teaching process. Another important aspect to take into account is planning. A lesson plan like the one shown in this article can serve as the basis of many others, since it can be adapted, modified or used partially in different writing courses. We, as instructors, only need some patience, a little of creativity, the suitable material to work with, and we will come up with a motivating and interesting lesson for our students. 


\section{REFERENCES}

Blackman, A. et al. (1993). The New Father. Time. 58-61.

Carson, J. (1993). Reading for writing: Cognitive perspectives. In J. Carson \& I. Leki (Eds.). Reading in the composition classroom: Second language perspectives (pp.85 - 104). Boston: Heinle \& Heinle.

Eisterhold, J. P. Carrell, S. Silberstein, B. Kroll \& P. A. Kwehin. (1990). Interactive Approaches to Second Language. Tesol Quarterly. 28 (2): 245-265.

Grabe, W. \& Kaplan, R. B. (1996). Theory and Practice of Writing. London: Longman.

Goodman, K. (1975). Language and literacy: In Gollasch, F. W. ( Ed.): The selected writings of Kenneth Goodman. London: Routledge and Kegan Paul.

Henley, E. (1993). The Joys and Risks of the "Daddy Track." Focus on American Culture. New Jersey: Regents/Prentice Hall.

Hughey, J., D. R. Wormuth, V. F. Hartfield \& H. L. Jacobs. (1983). Teaching ESL Composition, Principles and Techniques. Massachusetts: Newbury House Publishers, Inc.

Krashen, S. (1984). Writing: Research, theory and applications. Oxford: Pergamon Institute of English.

Kroll, B. (2003). (Ed.) Exploring the Dynamics of Second Language Writing. New York: Cambridge University Press.

Lopes, D. (1991). From Reading to Writing Strategies. English Teaching Forum. XXIX: 42-44.

Nunan, D. (1999). Second Language Teaching \& Learning. Boston: Heinle \& Heinle Publishers.

Reid, J. M. (1993). Teaching ESL Writing, New Jersey: Prentice Hall Regents.

Silberstein, S. (1987). Let's Take Another Look at Reading: Twenty Five Years of Reading Instruction. English Teaching Forum. XXV: 28-31.

Smalley, R. et al. (1995). Refining Composition Skills. Rhetoric \& Grammar. Boston: Heinle \& Heinle Publishers. 
APPENDIX A

\section{READING}

\section{THE NEW FATHER}

I. The redefinition of fatherhood has been going on in virtually every arena of American life for well over 20 years. As women worked to broaden their choices at home and work, the implicit invitations was for men to do likewise. As Levine has observed, Dr. Spock had carefully revised his advice on fathers by 1974 . The earlier version suggested that fathers change the occasional diaper and cautioned mothers about "trying to force the participations of fathers who get gooseflesh at the very idea of helping to take care of a baby." The new version of Baby and Child Care, by contrast, offered a prescription of the New Fatherhood: "The father - any father -should be sharing with the mother the day-to-day care of their child from birth onward...This is the natural way for the father to start the relationship, just as it is for the mother."

II. By the 80's, bookstores were growing fat with titles aimed at men: How to Father, Expectant Father, Pregnant Fathers, The Birth of a Father, Fathers Almanac and Father Power. There were books about child-and-father relations, like How to Father a Successful Daughter, and then specific texts for part-time fathers, single fathers, stepfathers, and homosexual fathers. Bill Cosby's Fatherhood was one of the bestselling books in publishing in history, and Good Morning, Merry Sunshine, by Chicago Tribune columnist Bob Greene, a journal about his first year of fatherhood, was on the New York Times bestseller list for almost a year. Parents can now pick up Parents' Sports, a new magazine dedicated to reaching the dad market with stories on the joys of soccer practice.

III. Institutions were changing too. In his book Fatherhood in America, published this month, Robert L. Griswold has traced the history of a fast-changing role that today not only allows men in the birthing room $(90 \%$ of fathers are in attendance at their child's birth) but also offers them postpartum courses in which new fathers learn how to change, feed, hold and generally take care of their infant. Some fathers may even get in on the pregnancy part by wearing the "empathy belly," a bulge size and weight of a third-trimester fetus. Suddenly available to men hoping to solidify the father-child bond are "Saturday with Daddy Outings, "special songfests, field trips and potlucks with dads. Even men behind bars could get help: one program allows an inmate father to read children's stories onto cassette tapes that are then sent, along with the book and a Polaroid picture of Dad, to his child.

IV. "It's become cool to be a dad," says Wyatt Andrews, a correspondent for CBS News who has three children: Rachel, 8, Averil, 7, and Conrad, 5. "Even at dinner parties, disciplinary techniques are discussed. Fathers with teenagers give advice about strategies to fathers with younger kids. My father was career Navy. I don't think he ever spent two seconds thinking about 
strategies of child rearing. If he said anything, it was, 'They listen to me.' "

\section{BRING BACK DAD}

V. These perceptual and behavorial shifts have achieved enough momentum to trigger a backlash of their own. Critics of the New Fatherhood are concerned that something precious is being lost in the revolution in parenting-some uniquely male contribution that is essential for raising healthy kids. In a clinical argument that sends off political steam, these researchers argue that fathers should be more than substitute mothers, that men parent differently than women and ways that matter enormously. They say a mother's love is unconditional, a father's love is more qualified, more tied to performance; mothers are worried about the infant's survival, fathers about future success. "In other words, a father produces not just children but socially viable children," says Blankenhorn. "Fathers, more than mothers, are haunted by the fear that their children will turn out to be bums, largely because a father understands that his child's character is, in some sense, a measure of his character as well."

V. When it comes to discipline, according to this school of thought, it is the combination of mother and father that yields justice tempered by mercy. "Mothers discipline children on a moment-by-moment basis," says Shapiro. "They have this emotional umbilical cord that lets them read the child. Fathers discipline by rules. Kids learn from their moms how to be aware of their emotional side. From dad, they learn how to live in society."

VII. As parents, some psychologists argue, men and women are suited for different roles at different times. The image of the New Fatherhood is Jack Nicholson surrounded by babies on the cover of Vanity Fair, the businessman changing tables in an airport men's room. But to focus only on infant care misses the larger point. "Parenting of young infants is not a natural activity for males, " says David Popenoe, an associate dean of social studies at Rutgers University who specializes in the family. He and others argue that women's voices are more soothing; they are better able to read the signals a child sends before he or she can talk. But as time passes, the strengths that fathers may bring to child rearing become more important.

VIII. "At a time when fatherhood is collapsing in our society," warns Blankenhorn, "when more children than ever in history are being voluntarily abandoned by their fathers, the only thing we can think of talking about is infant care? It's an anemic, adult-centered way of looking at the problem." Why not let mothers, he says, do more of the heavy lifting in the early years and let fathers do more of the heavy lifting after infancy when their special skills have more relevance? As children get older, notes William Maddox, director of research and policy at the Washington-based Family Research Council, fathers become crucial in their physical and psychological development. "Go to a park and watch father and mother next to a child on a jungle gym," he said. "The father encourages the kid to challenge 
himself by climbing to the top; the mother tells him to be careful. What's most important is to have the balance of encouragement along with a warning."

IX. This notion that men and women are genetically, or even culturally, predisposed to different parenting roles strikes other researchers as misguided. They are quick to reject the idea that there is some link between $X$ or $Y$ chromosomes and, say, conditional or unconditional love. "To take something that is only a statistical tendency," says historian Anthony Rotundo, "and turn it into a cultural imperative-fathers must do it this way and mothers msut do it that way-only creates problems for the vast number of people who don't it those tendencies, without benefiting the children at all." While researchers have found that children whose fathers are involved in their early rearing tend to have higher IQs, perform better in school and even have a better sense of humor, psychologists are quick to say this is not necessarily a gender issue. "It has to do with the fact that there are two people passionately in love with a child, "says Harvard's Brazelton.

X. The very fact that psychologists are arguing about the nature of fatherhood, that filmmakers are making movies based entirely on fatherlove, that bookstores see a growth market in father guides speaks not only to children's wellbeing but to men's as well. As much as families need fathers, men need their children in ways they are finally allowed to acknowledge, to learn from them all the secrets that children, with their untidy minds and unflagging hearts, have mastered and that grownups, having grown up, long to retrieve. -Reported by Ann Blackman/ Washington, Priscilla Painton/New York and James Willwerth/ Los Angeles

Taken from TIME, JUNE 28, 1993 


\section{APPENDIX B}

\section{Peer Review Checklist}

When you have finished writing the first draft of your essay, give it to a classmate to read and review. Use the following questions to respond to each other's essays.

Writer:

Reviewer:

Date:

Title of the essay:

1. What is the thesis of the essay? Write it here as a complete sentence:

2. What is the writer's attitude about the topic? Write it here:

3 What are the points of comparison or contrast the writer has chosen? List them briefly:

4. Are the points chosen significant and relevant? Why?

5. Are the points chosen sufficiently developed? Has the writer given enough detail, example, and explanation? Justify your answer. 
6. What pattern of organization has the writer used? Do you have any suggestions about the organization? Which ones?

7. Has the writer used transitions to give coherence? List them.

8. What is the most effective part of the essay? What has the writer done well? Why?

9. What is the least effective part of the essay? Suggestions. What would you change? Why?

10. What can you use in your essay from your partner's essay? 